\title{
Urocortin induces interleukin-6 release from rat cardiomyocytes through p38 MAP kinase, ERK and NF-KB activation
}

\author{
Man Huang ${ }^{1,2}$, Duraisamy Kempuraj ${ }^{2}$, Nikoletta Papadopoulou ${ }^{1,3}$, Taxiarchis Kourelis ${ }^{2}$, \\ Jill Donelan ${ }^{1,4}$, Akrivi Manola ${ }^{1}$ and Theoharis C Theoharides ${ }^{1,5,6}$ \\ ${ }^{1}$ Molecular Immunopharmacology and Drug Discovery Laboratory, Department of Pharmacology and Experimental Therapeutics and ${ }^{2}$ Bowles Center for Alcohol Studies, University of \\ North Carolina at Chapel Hill, CB\# 7178, Thurston Bowles Building, Chapel Hill, North Carolina 27599-7178, USA \\ ${ }^{3}$ Medical Faculty, Institute of Medical Microbiology, Immunology, and Hygiene, University of Cologne, Goldenfelsstraße 19-21, D-50935 Köln, Germany \\ ${ }^{4}$ Millennium Pharmaceuticals, 40 Landsdowne Street, Cambridge, Massachusetts 02139, USA \\ ${ }^{5}$ Departments of Internal Medicine and ${ }^{6}$ Biochemistry, Tufts University School of Medicine, Tufts Medical Center, 136 Harrison Avenue, Boston, Massachusetts 02111, USA
}

(Correspondence should be addressed to T C Theoharides; Email: theoharis.theoharides@tufts.edu)

\begin{abstract}
$\mathrm{CRH}$ and its structurally related peptide urocortin (Ucn) are released under stress. Ucn is a potent agonist for $\mathrm{CRH}-$ receptor 2 (CRH-R2), which is strongly expressed in rodent heart. Stress induces Ucn mRNA expression in the heart, where it may be cardioprotective. However, increasing evidence indicates that Ucn may also have pro-inflammatory actions. Here, we show that neonatal rat cardiomyocytes express $\mathrm{CRH}-\mathrm{R} 2$ by western blot analysis and Ucn induces interleukin-6 (IL-6) release in a time- and dose-dependent fashion. Ucn stimulates activation of ERK and p38 MAP kinases, while both MEK1 and p38 inhibitor block Ucn-induced IL-6 release. Ucn also activates nuclear factor kappa B

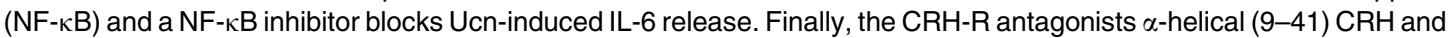
astressin-2B completely inhibit Ucn-induced IL-6 release, as well as activation of ERK, p38, and NF- $\mathrm{B}$. These findings indicate that Ucn induces IL-6 synthesis and release from neonatal rat cardiomyocytes. Our findings suggest that even though Ucn may confirm some protection on cardiomyocyte survival, it can also release IL-6, which is an independent risk factor for acute coronary syndrome. The precise role of cardiac Ucn in vivo remains to be elucidated.
\end{abstract}

Journal of Molecular Endocrinology (2009) 42, 397-405

\section{Introduction}

The stress response is regulated by $\mathrm{CRH}$, which activates the hypothalamic-pituitary-adrenal (HPA) axis typically leading to anti-inflammatory actions (Chrousos 1995). There are two main types of the G proteincoupled CRH receptors, CRH-receptor 1 (CRH-R1), and CRH-R2, which mediate the effects of the CRH family of structurally related peptides that includes $\mathrm{CRH}$, urotensin, sauvagine, and the urocortins (Ucn). Ucn binding to CRH-R2 is about 40 times more potent than for CRH itself. CRH-R1 is mainly expressed in the central nervous system (CNS) and anterior pituitary corticotrophs, activation of which leads to release of adrenocorticotropic hormone (Chrousos 1995). CRH-R2 has three different spliced forms, $\alpha, \beta$, and $\gamma$, of which CRH-R2 $\alpha$ is mainly in the CNS, while CRH-R2 $\beta$ is predominantly found in the periphery, especially in the heart (Nishikimi et al. 2000, Kimura et al. 2002) including cardiomyocytes (Okosi et al. 1998). Ucn mRNA is also expressed in the heart (Nishikimi et al. 2000). Species differences have been reported in the distribution of CRH-R2 in the cardiovascular system, showing $10 \times$ higher expression in mice than rats or humans cardiac muscle (Waser et al. 2006).

Ucn has been generally considered to be cardioprotective, especially in ischemia-reperfusion (IR) injury (Bale et al. 2003, Latchman 2003, Townsend et al. 2007), but is also increased (Nishikimi et al. 2000, Ikeda et al. 2003) with parallel decrease in cardiac CRH-R2 $\beta$ expression in cardiac hypertrophy (Nishikimi et al. 2000, Ikeda et al. 2003). On the other hand, acute stress, $\mathrm{CRH}$, and Ucn have been implicated in the pathophysiology of some neuroinflammatory disorders (Chrousos 1995, Karalis et al. 1997, Theoharides \& Cochrane 2004) and myocardial ischemia (MI; Jiang et al. 1996, Krantz et al. 2000). Acute stress elevates plasma interleukin-6 (IL-6) levels in rodents (Ando et al. 1998, Nukina et al. 2001) and such levels are higher in apolipoprotein E (Apo E) knockout mice that develop atherosclerosis (Huang et al. 2003).

Local inflammation is now recognized as a key component of coronary artery disease (CAD; Packard \& Libby 2008). The proinflammatory cytokine IL-6 is 
thought to contribute to the development of CAD (Huber et al. 1999), cardiomyopathy, congestive heart failure (Deliargyris et al. 2000) and MI (Miyao et al. 1993). IL-6 is a major inducer of $\mathrm{C}$ reactive protein (CRP) and both are elevated in and are associated with increased risk of CAD. The Health ABC study showed that plasma IL-6 levels had a stronger association with CAD than CRP (Cesari et al. 2003), while the PRIME study showed that only IL-6 remained significantly associated with MI (Luc et al. 2003). In another study, the incidence of future acute coronary events and mortality of patients with stable CAD or healed MI was strongly correlated with serum IL-6 levels over a 6-year observation (Fisman et al. 2006). In patients with acute coronary syndrome (ACS), plasma IL-6 was increased and appeared to derive primarily from a cardiac source (Deliargyris et al. 2000), but the exact cell type remains known. Cardiomyocytes are capable of releasing IL-6 in response to hypoxia and to cytokines (Yamauchi-Takihara et al. 1995, Coste et al. 2001).

Here, we show for the first time that neonatal rat cardiomyocytes express CRH-R2 protein and secrete IL-6 in response to Ucn through the activation of CRHR2 and subsequently MAP kinases and nuclear factor kappa B (NF-кB).

\section{Materials and methods}

\section{Culture of neonatal rat cardiomyocytes}

This protocol was approved by the Institutional Animal Care Committee. Ventricular cardiomyocytes were isolated from the hearts of 1-3-day old neonatal male Sprague/Dawley rats (Charles River Laboratories, Inc., Wilmington, MA, USA) using the Neonatal Cardiomyocyte Isolation System (Worthington Biochemical Corporation, Lakewood, NJ, USA). Cardiomyocytes were enriched by preplating for $60 \mathrm{~min}$ to allow the non-myocytes to adhere to the plate. Non-adherent cardiomyocytes were then removed by aspiration and plated in DMEM/F-12 (Gibco) supplemented with $5 \%$ fetal bovine serum (Hyclone, Logan, UT, USA), $10 \%$ horse serum (Sigma), $1 \%$ penicillin/streptomycin (Gibco), $20 \mu \mathrm{M}$ vitamin $\mathrm{B}_{12}$ (Sigma) at $37^{\circ} \mathrm{C}$ in $95 \%$ air $5 \% \mathrm{CO}_{2}$. For the first 3 days of culture, $0.1 \mathrm{mM}$ 5-bromo-2'-deoxyuridine (BrdU, Sigma) was added to the medium to prevent proliferation of non-myocytes. The culture medium was changed $40-48 \mathrm{~h}$ following seeding, to serum depleted medium: DMEM/F-12 supplemented with $1 \times$ insulin-transferrin-selenium (Gibco), $0.5 \%$ penicillin/streptomycin, $1 \%$ fetal bovine serum and $20 \mu \mathrm{M}$ vitamin $\mathrm{B}_{12}$; cardiomyocytes remained in this medium for $24 \mathrm{~h}$ before further experiments. All cells in culture were seen beating spontaneously, indicative of cardiomyocytes. Ucn is expressed in cells of the immune system (Karalis et al. 1997) including mast cells (Kempuraj et al. 2004).

We stained the cardiomyocytes with $1 \%$ toluidine blue solution $(\mathrm{pH}<2)$ for mast cells and with Giemsa stain for lymphocytes in the final cardiomyocyte preparation. Electron microscopy confirmed the absence of any fibroblasts or endothelial cells (data not shown).

\section{IL-6 measurements}

Time-course and dose-response studies of Ucn-stimulated IL-6 release from cardiomyocytes were conducted. Cells were either treated with $100 \mathrm{nM} \mathrm{Ucn}$ for different periods of time $(0-72 \mathrm{~h})$, or treated with different concentrations of Ucn $(0-10 \mu \mathrm{M})$ for $48 \mathrm{~h}$; following stimulation, the culture medium was collected and was assayed for IL-6 using the quantitative sandwich enzyme immunoassay technique (R\&D).

\section{Cyclic AMP assays}

Cardiomyocytes were incubated in serum-free culture medium containing $100 \mathrm{nM}$ Ucn for the designated times and cAMP was measured with an ELISA kit (R\&D) as previously described (Heldwein et al. 1996).

\section{Western blot analysis}

For the detection of CRH-R2, heart tissue and isolated cardiomyocytes were disrupted in ice-cold lysis buffer (50 mM Tris pH 8.0, $150 \mathrm{mM} \mathrm{NaCl}, 0 \cdot 1 \%$ SDS, $0 \cdot 02 \%$ sodium azide, $1 \% \mathrm{NP}-40,0.5 \%$ sodium deoxycholate, $100 \mu \mathrm{g} / \mathrm{ml} \mathrm{PMSF}$, and $1 \mu \mathrm{g} / \mathrm{ml}$ aprotinin) and were then centrifuged at $15000 \mathrm{~g}$ for $15 \mathrm{~min}$ at $4{ }^{\circ} \mathrm{C}$. For the detection of phosphorylation of MAP kinases, cardiomyocytes were exposed to $100 \mathrm{nM} \mathrm{Ucn}$ in the presence or absence of inhibitors for the indicated time, after which the cells were lysed in lysis buffer, vortexed, and centrifuged at $15000 \mathrm{~g}$ for $15 \mathrm{~min}$ at $4^{\circ} \mathrm{C}$. Aliquots of tissue and cell lysates were kept for protein estimation (Bio-Rad). An equal amount of protein from each sample was mixed with an equal volume of 3X SDS sample buffer. The samples were boiled for $3 \mathrm{~min}$ and proteins were subjected to electrophoresis on a $10 \%$ SDS-polyacrylamide gel, subsequently transferred onto the PVDF membrane (Immobilon-P) by the semi-dry method (BioRad). The membrane was then blocked with 5\% dry milk in PBS containing $0.05 \%$ Tween-20 (PBS-T) and probed for $2 \mathrm{~h}$ at room temperature with two different rabbit polyclonal anti-CRH-R2 antibodies (Santa Cruz Biotechnology, Santa Cruz, CA, USA) and (Imgenex, San Diego, CA, USA) or an antibody that detects phospho-ERK and phospho-p38 (Cell Signaling Danvers, MA, USA). For the detection of total ERK 
and $\mathrm{p} 38$, the membrane was probed for $1 \mathrm{~h}$ at room temperature with either an anti-ERK1 antibody or an anti-p38 antibody. The membrane was washed in PBS-T and incubated with a HRP-conjugated secondary antibody (Santa Cruz) for $1 \mathrm{~h}$. The immunoreactive bands were visualized by enhanced chemiluminescence (ECLJ).

\section{Electromobility gel shift assays}

The nuclear extract of cardiomyocytes was collected as previously described (Li et al. 2001). The consensus

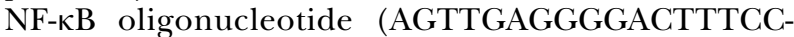
CAGGC, Santa Cruz) was radiolabeled by mixing $50 \mathrm{ng}$ oligonucleotide, $70 \mu \mathrm{Ci}\left[\gamma^{32} \mathrm{P}\right]$ ATP, $1 \mu \mathrm{l}$ T4 polynucleotide kinase, $1.5 \mu \mathrm{l} 10 \times \mathrm{T} 4$ polynucleotide buffer and double-distilled water in a $15 \mu$ l reaction volume. The nuclear extract protein $(10 \mu \mathrm{g})$ was then

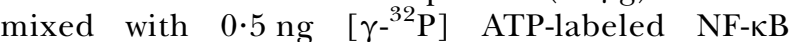
oligonucleotide, $20 \mu \mathrm{g}$ BSA, $2 \mu \mathrm{g}$ pdI-dC, $2 \mu \mathrm{l}$ Buffer $\mathrm{D}+(20 \mathrm{mM}$ Hepes $\mathrm{pH} 7 \cdot 9,20 \%$ glycerol, $100 \mathrm{mM} \mathrm{KCl}$, $0.5 \mathrm{mM}$ EDTA, $0.25 \%$ NP40), $4 \mu \mathrm{l}$ Buffer F $(20 \%$ FICOLL 400, $100 \mathrm{mM}$ Hepes $\mathrm{pH} 7 \cdot 9,300 \mathrm{mM} \mathrm{KCl}$ ), and DTT $(2 \mathrm{mM})$ in $20 \mu \mathrm{l}$ total volume at room temperature for $20 \mathrm{~min}$. At the end of the reaction, the mixture was loaded on a non-denaturing $4 \%$ polyacrylamide gel using a running buffer containing $50 \mathrm{mM}$ Tris $\mathrm{pH} 7 \cdot 5,0.38 \mathrm{M}$ glycine, and $2 \mathrm{mM}$ EDTA, after which the gel was dried and exposed to Kodak $\mathrm{X}$-ray film for autoradiography at $-80^{\circ} \mathrm{C}$.

\section{Drug pretreatment}

Cardiomyocytes were pretreated with the p38 MAP kinase inhibitor SB203580 $(10 \mu \mathrm{M})$ or the MEK1 inhibitor PD98059 $(20 \mu \mathrm{M}) 1 \mathrm{~h}$ before Ucn treatment. The NF- $\kappa$ B inhibitor pyrrolidine dithiocarbamate (PDTC) was added at $50 \mu \mathrm{M}$ to the culture medium $2 \mathrm{~h}$ before Ucn treatment. The peptide CRH-R antagonists $\alpha$-helical (9-41) CRH or astressin-2B $(10 \mu \mathrm{M})$ were added $1 \mathrm{~h}$ before Ucn treatment. The optimal concentrations and the duration of pretreatment for all the inhibitors used were predetermined by time- and dose-response experiments (not shown). All concentrations of the different inhibitors used in these experiments have been previously shown not to be toxic to cardiomyocytes; moreover, the viability of the cardiomyocytes was intact, as they were still beating and Trypan blue exclusion was minimal at $48 \mathrm{~h}$.

\section{Statistical analysis}

Each experiment was performed at least four times unless stated otherwise. The differences between unstimulated and stimulated cells were compared using both the two-tailed Student's $t$-test and the nonparametric Mann-Whitney U-test; comparison between different treatment groups was performed by ANOVA using one-way ANOVA. Results are presented as mean \pm s.E.M. For all analyses, $P<0.05$ was considered to indicate statistical significance.

\section{Results}

Time- and dose-dependent increase of IL- 6 release by urocortin

Ucn increased IL-6 release from isolated cardiomyocytes in a time- and dose-dependent fashion. Significant increase of IL-6 release was observed as early as $4 \mathrm{~h}$ of Ucn $(100 \mathrm{nM})$ exposure. Ucn produced $15.5 \pm$ $0.5 \mathrm{pg} / \mathrm{ml}$ of IL-6 as compared with $7 \cdot 1 \pm 1.4 \mathrm{pg} / \mathrm{ml}$ from unstimulated cells (Fig. 1A, $n=6, P<0 \cdot 05$ ). The Ucn-induced IL-6 release increased with time and maximal release was observed at $48 \mathrm{~h}$ of stimulation when Ucn treated cells produced $120 \cdot 2 \pm 9 \cdot 5 \mathrm{pg} / \mathrm{ml}$ as
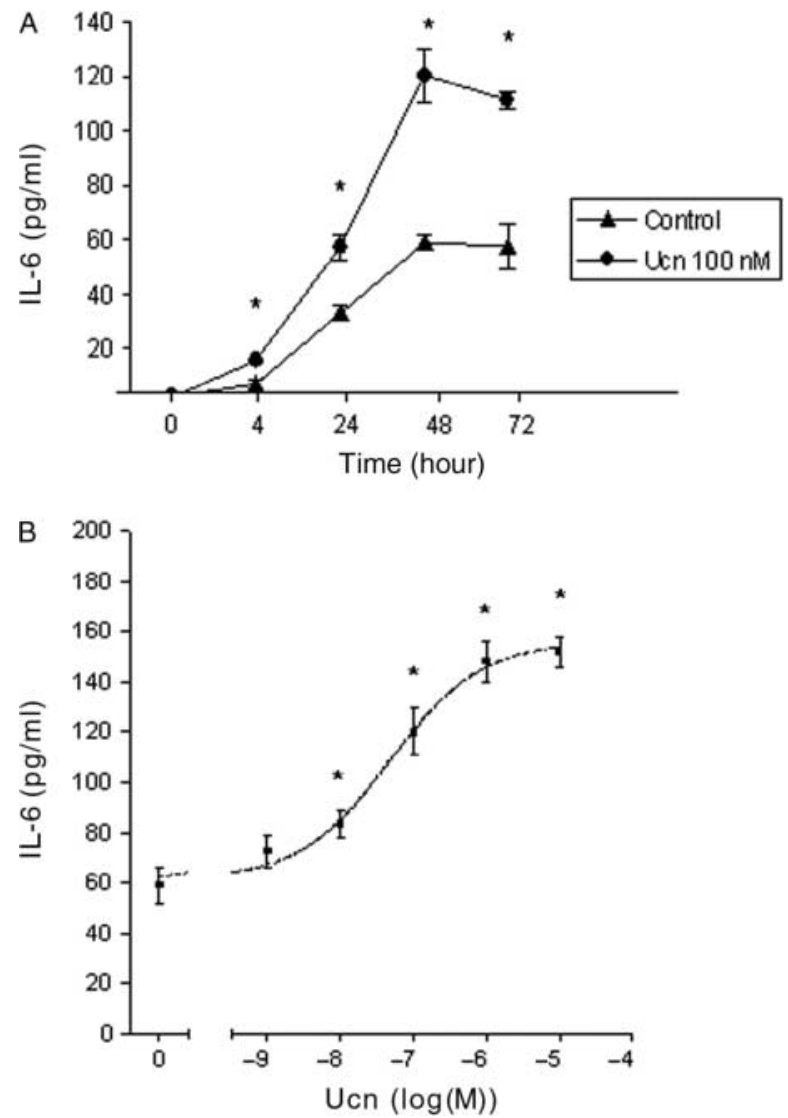

Figure 1 Time- and dose-dependent effect of Ucn on IL-6 release from cardiomyocytes. (A) Cells were stimulated with $100 \mathrm{nM} \mathrm{Ucn}$ in serum-free medium for the designated length of time $(0-72 \mathrm{~h})$. (B) Cells were treated with different concentrations of Ucn $(0-10 \mu \mathrm{M})$ for $48 \mathrm{~h}\left(n=6 ;{ }^{*} P<0 \cdot 05\right)$. 
compared with $59 \cdot 1 \pm 7 \cdot 2 \mathrm{pg} / \mathrm{ml}$ of IL-6 from untreated cells (Fig. 1A, $n=6, P<0 \cdot 05$ ). Unstimulated cells also released more IL- 6 over time, but the difference between them and the treatment group remained significant at every time point (Fig. 1A). Ucn-induced IL-6 release from cardiomyocytes was also dose-dependent. When cells were treated with different concentrations of Ucn for $48 \mathrm{~h}, 10 \mathrm{nM}$ was the lowest concentration of Ucn that could stimulate significant IL-6 increase of $83 \cdot 5 \pm 5 \cdot 5 \mathrm{pg} / \mathrm{ml}$ versus $59 \cdot 1 \pm 7 \cdot 2 \mathrm{pg} / \mathrm{ml}$ in controls (Fig. 1B, $n=6, P<0 \cdot 05$ ). Maximal IL-6 release of $148 \cdot 3 \pm 8 \cdot 1 \mathrm{pg} / \mathrm{ml}$ was induced by $1 \mu \mathrm{M}$ of Ucn (Fig. 1B, $n=6, P<0 \cdot 05$ ); higher Ucn concentrations $(10 \mu \mathrm{M})$ did not increase IL-6 release any further $(152 \cdot 0 \pm 6 \cdot 1 \mathrm{pg} / \mathrm{ml}$, Fig. $1 \mathrm{~B}, n=6)$.

\section{Presence of CRH-R2 in cardiomyocytes}

Western blot analysis using anti-CRH-R2 antibodies from two different sources demonstrated the presence of a strong immunoreactive band of about $49 \mathrm{kDa}$ in mouse and rat heart, as well as in neonatal rat cardiomyocytes (positive controls included rat cortex and cerebellum; Fig. 2A-C). Use of a blocking peptide for CRH-R2 abolished immunoreactivity, while one for CRH-R1 had no effect (data not shown). There was no CRH-R1 expression noted (data not shown). In order to investigate whether the CRH-R2 on cardiomyocytes is functional, cellular cAMP levels were measured following Ucn stimulation, since CRH and related peptides typically bind to CRH-R and activate adenylate cyclase. Production of cAMP increased significantly by $3 \cdot 4 \pm 0 \cdot 2$-fold above basal levels after 2 min of stimulation with $100 \mathrm{nM} \mathrm{Ucn}$, reaching a maximum of $6 \cdot 9 \pm 0 \cdot 2$-fold above basal level $(n=6$, $P<0.05)$ at $5 \mathrm{~min}$, and then decreased slowly over time, but still remained $5 \cdot 3 \pm 0 \cdot 1$-fold above basal values at 20 min (results not shown).

\section{Urocortin activates ERK and p38 MAP kinases}

In order to study the possible mechanism(s) by which Ucn stimulates IL-6 release, we investigated the effect of Ucn on the phosphorylation of MAP kinases, including ERK and p38. Cardiomyocytes responded to $100 \mathrm{nM}$ Ucn with the activation of both ERK and p38. Phosphorylation of ERK (p44/42) was observed at $2 \mathrm{~min}$ and was maximized at $5 \mathrm{~min}$ after which it decreased over time, but remained above basal level up to $1 \mathrm{~h}$ (Fig. 3A).

The peptide CRH-R inhibitor astressin completely reversed the effect of Ucn (100 nM for $15 \mathrm{~min}$ ) on ERK activation (Fig. 3A). Pretreatment with PD98059 (200 $\mathrm{nM}$ for $1 \mathrm{~h})$, the specific inhibitor of MEK1, which is the upstream stimulator of ERK, also
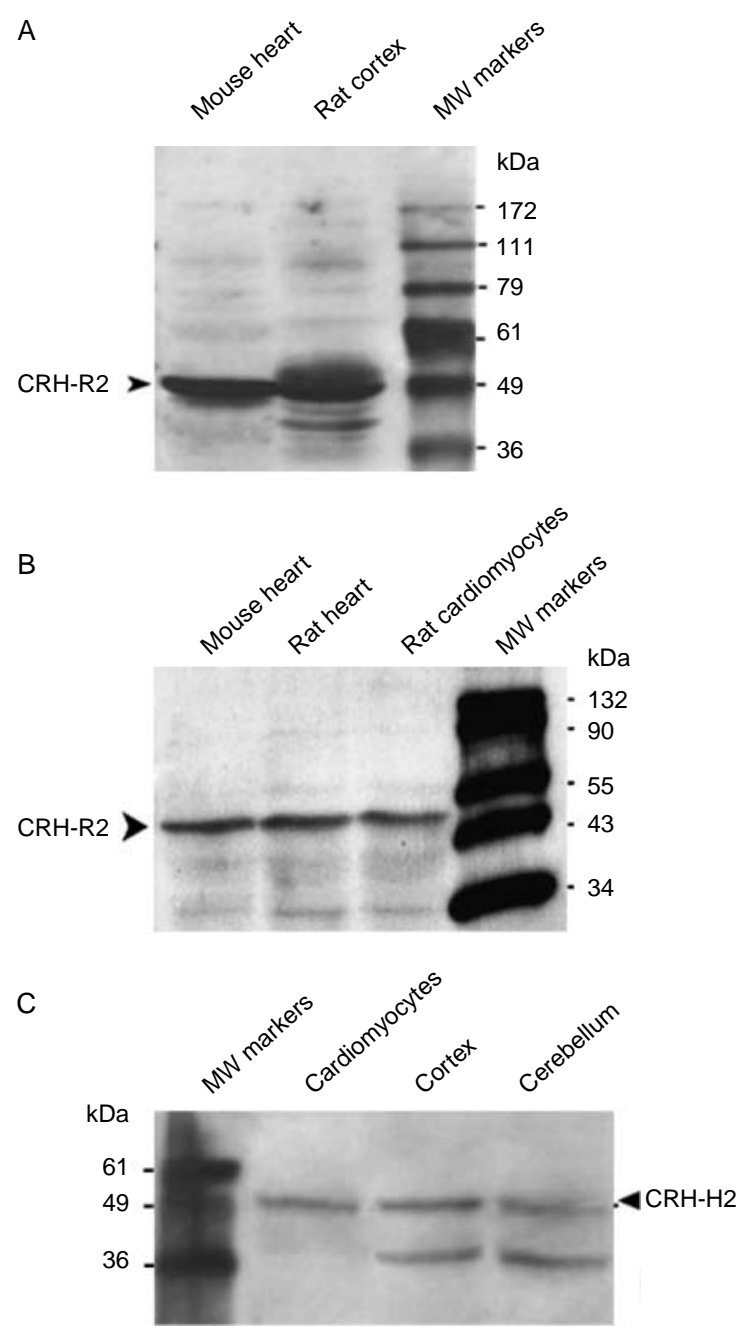

Figure 2 Western blot analysis of $\mathrm{CRH}-\mathrm{R} 2$ in rodent hearts and isolated neonatal rat cardiomyocytes. (A) Mouse heart with rat cortex homogenates included as a positive control. (B) Mouse heart, rat heart homogenates, and rat cardiomyocytes ( $A$ \& $B$ using anti-CRH-R2 from Santa Cruz, CA, USA). (C) Rat cardiomyocytes with rat cortex and cerebellum as positive controls using a rabbit polyclonal anti-CRH-R2 antibody from Imgenex (San Diego). Representative gels $(n=3)$. The amount of protein loaded for this gel was about $1 / 5$ th of gels shown in Fig. $2 \mathrm{~A}$ and $2 \mathrm{~B}$ due to limited availability of cardiomyocyte material.

completely inhibited the phosphorylation of ERK. The specific inhibitor of p38 MAP kinase SB203580 $(100 \mathrm{nM})$ had no apparent effect on ERK activation (Fig. 3A). There was no difference in total ERK between control samples, the positive control stimulated by IL-1 $\beta$ and Ucn (Fig. 3A, lower panel).

Phosphorylation of p38 MAP kinase occurred later than that of ERK (Fig. 3A and B); there was a moderate increase of p38 phosphorylation observed at $15 \mathrm{~min}$ of Ucn exposure (Fig. 3B). Both CRH-R antagonists, $\alpha$-helical (9-41) CRH and astressin completely 
A

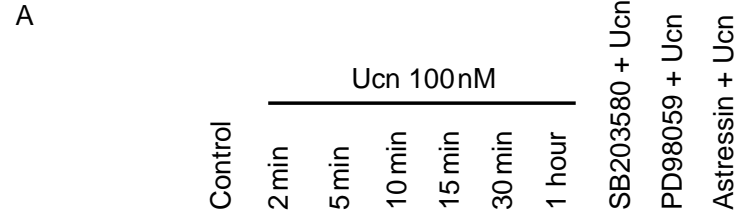

Phospho-p44 Phospho-p42

Phospho-p42
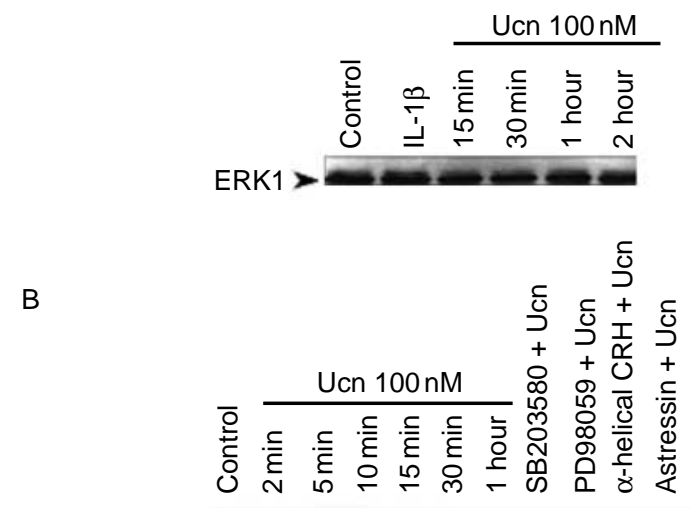

Phospho-p38 > - - - - - - -

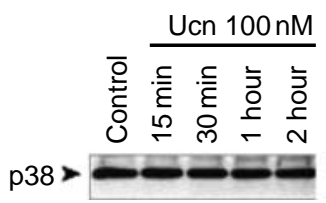

Figure 3 Effect of Ucn on phosphorylation of MAP kinases by western blot analysis. (A) Phosphorylation of ERK and effects of the peptide $\mathrm{CRH}-\mathrm{R}$ antagonist astressin $(10 \mu \mathrm{M})$, as well as the specific inhibitor of p38 MAP kinase SB203580 $(10 \mu \mathrm{M})$ and the specific inhibitor of MEK1 PD98059 (20 $\mu \mathrm{M})$ for $1 \mathrm{~h}$ (upper panel); total ERK was detected using an antibody to ERK1 and remained at the same level in unstimulated cells, those treated with IL-1 $\beta$ (10 ng/ml for $10 \mathrm{~min}$ ) or Ucn-treated cells. (B) Phosphorylation of p38 MAP kinase and effects of $\alpha$-helical (9-41) CRH and astressin, as well as SB203580 and PD98059 (upper panel); total p38 remained at the same level (lower panel) in both unstimulated cells and Ucn-treated cells (representative gel from $n=5$; ${ }^{\star} P<0.05$ ).

inhibited Ucn (100 nM for $15 \mathrm{~min}$ )-induced phosphorylation of p38. Since SB203580 inhibits the downstream signaling pathway of p38, it did not inhibit the phosphorylation of p38 itself (Fig. 3B); as expected, the MEK1 inhibitor PD98059 did not inhibit p38 phosphorylation either (Fig. 3B). The total p38 remained the same in Ucn-stimulated and unstimulated cells (Fig. 3B lower panel).

\section{Urocortin activates NF- $\mathrm{KB}$}

There was moderate activation of NF- $\mathrm{B}$ after Ucn treatment (100 nM, $15 \mathrm{~min}$ to $6 \mathrm{~h}$ duration), as shown by gel-shift assay (Fig. 4A). Both $\alpha$-helical CRH (9-41) and SB203580 completely inhibited Ucn (100 nM for 15 min)-induced NF- $\kappa$ B activation (Fig. 4A), suggesting that the activation of NF- $\kappa \mathrm{B}$ in cardiomyocytes is mediated by CRH-R and is dependent on p38 phosphorylation. Pretreatment with PD98059 $(20 \mu \mathrm{M}$ for $1 \mathrm{~h}$ ) unexpectly did not have any effect on NF-KB activation. Supershift assay using an antibody against the p50 subunit of NF- $\mathrm{BB}$ confirmed that the Ucnstimulated increase in binding resulted from NF- $\kappa B$ activity in the nuclear extracts of Ucn-treated cells (Fig. 4B).

\section{Urocortin increases IL-6 release by a CRH-R2-induced MAP kinase- and NF-KB-dependent mechanism}

In order to determine whether Ucn-induced IL-6 release from cardiomyocytes involves MAP kinases or $\mathrm{NF}-\kappa \mathrm{B}$ activation, cardiomyocytes were pretreated for $1 \mathrm{~h}$ before Ucn $(100 \mathrm{nM})$ stimulation with either the p38 MAP kinase inhibitor SB203580 $(10 \mu \mathrm{M})$ or the MEK1 inhibitor PD98059 $(20 \mu \mathrm{M})$. Otherwise, cardiomyocytes were pretreated with the NF- $\mathrm{B}$ inhibitor PDTC $(50 \mu \mathrm{M})$ for $2 \mathrm{~h}$ before Ucn addition. As shown in Fig. 5A, both SB203580 and PD98059 completely inhibited Ucn-induced IL-6 release, indicating that both p38 and ERK are involved in Ucn-stimulated IL-6 release from cardiomyocytes. PDTC $(50 \mu \mathrm{M}$ for $1 \mathrm{~h})$ also completely inhibited IL-6 release stimulated by $\mathrm{Ucn}$, further indicating the involvement of NF- $\kappa \mathrm{B}$. Both $\alpha$-helical CRH (9-41) and astressin (100 nM) completely inhibited Ucn-induced IL-6 release (Fig. 5B), confirming that Ucn exerts its effect on IL-6 release through the activation of CRH-R.

\section{Discussion}

Here, we show for the first time that Ucn stimulates IL-6 release from neonatal rat cardiomyocytes. CRH-R2 appears to be involved, since it is identified in cardiac tissue and in isolated cardiomyocytes by immunoblotting, and the release of IL-6 is blocked by astressin-2B. CRH-R2 was detected by antibodies from two different sources, using rat cortex and cerebellum as positive controls. The same Santa-Cruz antibody used here was previously reported to be specific (Bishop et al. 2006), and also identified a band around $49 \mathrm{kDa}$. Moreover, the western blot with the second anti-CRHR2 antibody from Imgenex also generated a band around $49 \mathrm{kDa}$, as shown in the product specification. A similar molecular weight band is also recognized by one more anti-CRH-R2 antibody (data not shown) by Novus Biologicals (Littleton, CO, USA; www.novusbio. com/data_sheet/index/NB100-56485). Some authors have reported the molecular weight for the full length CRH-R2 to be about $70 \mathrm{kDa}$ in the pituitary, but lower in 


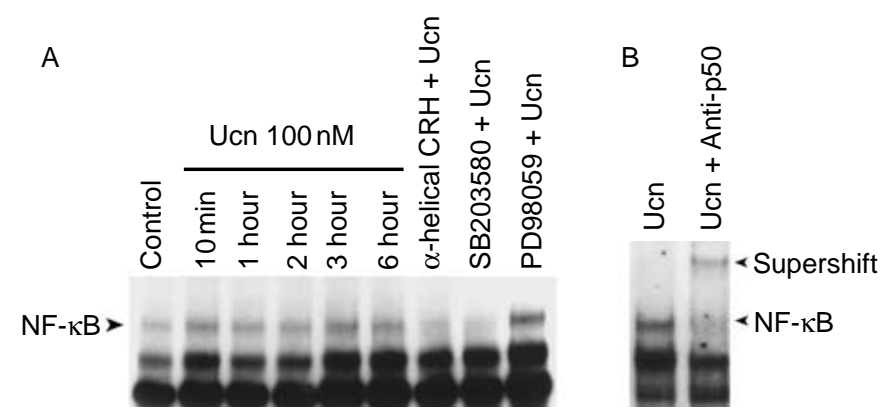

Figure 4 Effect of Ucn on NF- $\mathrm{BB}$ in cardiomyocytes. (A) NF- $\mathrm{B}$ activation demonstrated by binding of NF- $\mathrm{KB}$ to the radiolabeled oligonucleotide shown by EMSA and effects of $\alpha$-helical (9-41) $\mathrm{CRH}$, SB203580 $(10 \mu \mathrm{M})$ and PD98059 $(20 \mu \mathrm{M})$. (B) Supershift assay using antibody against the p50 subunit of NF- $\kappa B$ confirmed that the Ucnstimulated increase in binding resulted from NF- $\kappa B$ activity in the nuclear extracts of Ucn-treated cells (representative gel from $n=5$; $\left.{ }^{\star} P<0.05\right)$.

the brain (Grigoriadis \& De Souza 1988); the $49 \mathrm{kDa}$ band may represent a CRH-R2 form that may be truncated, with less glycosylation, or a tissue specific variant.

Ucn and CRH-R2 $\alpha$ mRNA expression has been detected in cardiac tissue with CRH-R2 $\beta$ predominantly expressed in the left ventricle (Kimura et al. 2002). CRH-R2 protein expression was shown by
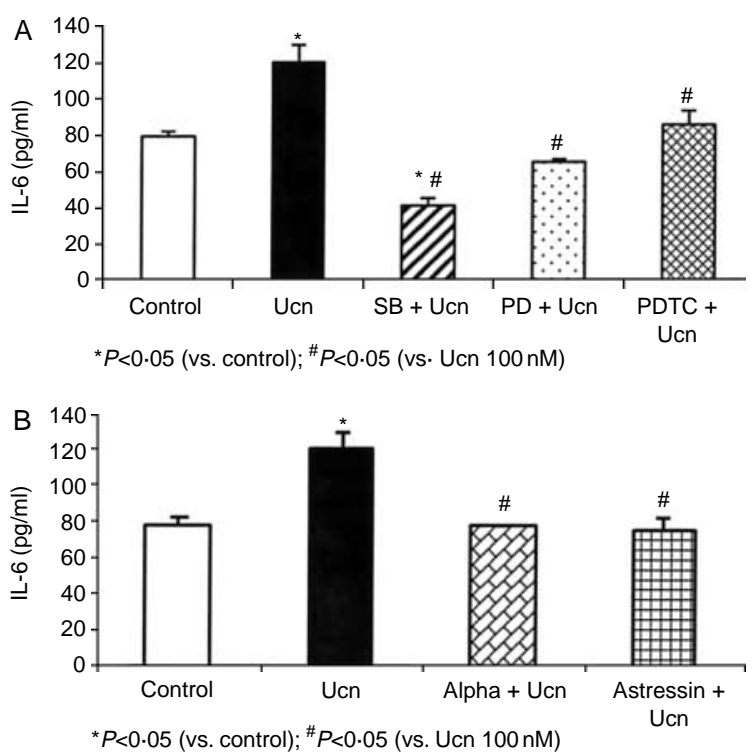

Figure 5 Ucn increases IL- 6 release in cardiomyocytes through CRHR MAP kinase and NF- $\kappa$ B. (A) Pretreatment with SB203580 at $10 \mu \mathrm{M}, \mathrm{PD} 98059$ at $20 \mu \mathrm{M}$ for $1 \mathrm{~h}$ before Ucn stimulation $(100 \mathrm{nM}, 48 \mathrm{~h})$ or the NF-KB inhibitor pyrrolidine dithiocarbamate (PDTC) at $50 \mu \mathrm{M} 2 \mathrm{~h}$ before Ucn stimulation (100 nM, $48 \mathrm{~h})(n=6$; ${ }^{\star} P<0.05$ versus control; ${ }^{\#} P<0.05$ versus Ucn $\left.100 \mathrm{nM}\right)$.

(B) Pretreatment with $\alpha$-helical (9-41) CRH or astressin-2B at $10 \mu \mathrm{M}$ for $1 \mathrm{~h}$ before Ucn stimulation $(100 \mathrm{nM}, 48 \mathrm{~h})(n=5$; ${ }^{\star} P<0.05$ versus control; ${ }^{\#} P<0.05$ versus Ucn $\left.100 \mathrm{nM}\right)$. autoradiography using a specific radiolabeled antiCRH-R2 ligand to be very high in rodent heart, with very little CRH-R1 detected (Waser et al. 2006). CRH-R2ß mRNA expression was depressed in left ventricular hypertrophy, possibly through downregulation by Ucn (Nishikimi et al. 2000). Restraint stress upregulated Ucn mRNA, but decreased CRH-R2 $\beta$ mRNA levels in the rat heart and aorta (Pournajafi et al. 2003). CRH-R2 mRNA expression was also downregulated by IL-1 and TNF in the mouse heart (Coste et al. 2001), possibly acting to limit the inotropic and chronotropic effects of $\mathrm{Ucn}$.

Ucn II was shown to stimulate rat neonatal cardiomyocytes to release atrial nitriuretic peptide in a CRH-R2 and cAMP-dependant manner (Ikeda et al. 2005). Ucn mediates stress-induced IL-6 release in vivo and administration of Ucn causes elevation of plasma IL-6 in rats (Ando et al. 1998). Ucn also stimulates IL-6 secretion from human peripheral mononuclear cells in vitro (Kohno et al. 2001), as well as an increase in IL-6 mRNA levels through CRH-R2 in rat aortic smooth muscle cells (Kageyama et al. 2007).

Our study demonstrates that IL-6 release by Ucn involves p38 MAP kinase, ERK and NF- $\mathrm{B}$ activation. Our results are consistent with a previous study that showed p38 MAP kinase activation by Ucn, but not $\mathrm{CRH}$, in cultured human pregnant myometrial cells

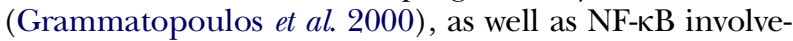
ment in TNF-induced IL-6 expression and release from cardiomyocytes (Craig et al. 2000) and upregulation of inflammatory IL-6 expression (TNF- $\alpha$, IL-1 and IL-6) in cardiomyocyte hypertrophy (Purcell et al. 2001). Surprisingly, our results show that while Ucn-induced IL-6 release requires NF- $\kappa \mathrm{B}$ activation, Ucn-induced NF- $\kappa \mathrm{B}$ activation does not appear to require ERK. This discrepancy may indicate that ERK1 / 2 contributes to Ucn stimulation of IL-6 production independent of NF- $\kappa$ B. 
The role of Ucn in the heart is far from clear. Ucn protects the rat heart from IR injury in vitro and in vivo through upregulation of the p42/p44 MAPK pathway (Schulman et al. 2003). Ucn-II and Ucn-III are also cardioprotective against IR injury (Brar et al. 2004, Woodcock 2004). Stimulation of CRH-R2 $\beta$ by Ucn-II and III resulted in cAMP-independent ERK1/2 phosphorylation during IR and reduced infarct size (Brar et al. 2004). Both Ucn (Brar et al. 2000) and IL-6 (Craig et al. 2000) may protect neonatal rat cardiomyocytes from apoptosis induced by hypoxia. However, while i.v. administration of Ucn-II had inotropic and chronotropic effects in mice and humans, it decreased blood pressure, effects absent in CRH-R2 knockout mice (Bale et al. 2004, Davis et al. 2007). Ucn-II also decreased mean arterial blood pressure in the rat, which was blocked by the CRH-R2 antagonist anti-sauvagine without any effect on normal cardiac function (Mackay et al. 2003). Ucn is released before and independently of cardiomyocyte death (Knight et al. 2008) and could have proinflammatory actions (Chrousos 1995) through a mechanism that involves mast cells (Theoharides et al. 2004) as in allergic asthma (Wu et al. 2006), and in intestinal inflammation (Kokkotou et al. 2006, Wu et al. 2006) in rats.

Cardiomyocyte-derived IL-6 in response to Ucn may even have dual and opposing actions. It might originally lead to inhibition of apoptosis, but eventually to hypertrophy alone or following angiotensin II (Sano et al. 2000). In macrophages, both CRH-R1 and CRH-R2 agonists have an early anti-inflammatory, but delayed pro-inflammatory effect on TNF- $\alpha$ release (Tsatsanis et al. 2007). The particular effects of Ucn may depend on the stage of maturation of the cardiomyocytes and/or activation of specific CRH-R2 isoforms, documented in keratinocytes (Pisarchik \& Slominski 2004) and mast cells (Cao et al. 2005). For instance, a soluble CRH-R2 $\alpha$ isoform was shown to neutralize the effect of CRH-R agonists (Chen et al. 2005), while Ucn mRNA antisense transcripts have been identified in rat tissue (Shi et al. 2000).

Acute stress is implicated in cardiovascular pathology (Theoharides \& Cochrane 2004), especially in eliciting MI in patients with CAD (Jiang et al. 1996). Acute stress elevates plasma IL-6 levels in rodents (Ando et al. 1998, Nukina et al. 2001) and such levels are higher in ApoE knockout mice that develop atherosclerosis (Huang et al. 2003). IL-6 plays a crucial role in MI (Miyao et al. 1993), CAD (Huber et al. 1999), cardiac hypertrophy (Sano et al. 2000), and congestive heart failure (Deliargyris et al. 2000). IL-6 expression is also increased in coronary arteries of aged rats that are more prone to atherosclerosis and CAD (Cesari et al. 2003). The importance of inflammation including IL-6 and its stimulation of CRP production in atherosclerosis was reviewed recently (Packard \& Libby 2008).
Elevated intracoronary levels of IL-6 (Deliargyris et al. 2000) shown in patients with acute CAD may also be involved in coronary hypersensitivity leading to Kounis syndrome (Kounis et al. 2007). Consequently, any suggestion that Ucn peptides could be used therapeutically for heart conditions may be too premature.

\section{Declaration of interest}

The authors declare that there is no conflict of interest that could be perceived as prejudicing the impartiality of the research reported.

\section{Funding}

This work was supported in part by Theta Biomedical Consulting and Development Co. Inc., (Brookline, MA) to TCT.

\section{Acknowledgements}

We thank Mrs Jessica Christian for her word processing skills.

\section{References}

Ando T, Rivier J, Yanaihara H \& Arimura A 1998 Peripheral corticotropin-releasing factor mediates the elevation of plasma IL-6 by immobilization stress in rats. American Journal of Physiology $\mathbf{2 7 5}$ R1461-R1467.

Bale TL, Giordano FJ \& Vale WW 2003 A new role for corticotropinreleasing factor receptor-2: suppression of vascularization. Trends in Cardiovascular Medicine 13 68-71.

Bale TL, Hoshijima M, Gu Y, Dalton N, Anderson KR, Lee KF, Rivier J, Chien KR, Vale WW \& Peterson KL 2004 The cardiovascular physiologic actions of urocortin II: acute effects in murine heart failure. PNAS 101 3697-3702.

Bishop GA, Tian JB, Stanke JJ, Fischer AJ \& King JS 2006 Evidence for the presence of the type 2 corticotropin releasing factor receptor in the rodent cerebellum. Journal of Neuroscience Research 84 1255-1269.

Brar BK, Jonassen AK, Stephanou A, Santilli G, Railson J, Knight RA, Yellon DM \& Latchman DS 2000 Urocortin protects against ischemic and reperfusion injury via a MAPK-dependent pathway. Journal of Biological Chemistry 275 8508-8514.

Brar BK, Jonassen AK, Egorina EM, Chen A, Negro A, Perrin MH, Mjos OD, Latchman DS, Lee KF \& Vale W 2004 Urocortin-II and urocortin-III are cardioprotective against ischemia reperfusion injury: an essential endogenous cardioprotective role for corticotropin releasing factor receptor type 2 in the murine heart. Endocrinology 145 24-35.

Cao J, Papadopoulou N, Kempuraj D, Boucher WS, Sugimoto K, Cetrulo CL \& Theoharides TC 2005 Human mast cells express corticotropin-releasing hormone (CRH) receptors and CRH leads to selective secretion of vascular endothelial growth factor. Journal of Immunology 174 7665-7675.

Cesari M, Penninx BW, Newman AB, Kritchevsky SB, Nicklas BJ, Sutton-Tyrrell K, Tracy RP, Rubin SM, Harris TB \& Pahor M 2003 Inflammatory markers and cardiovascular disease (the health, aging and body composition (health ABC) study). American Journal of Cardiology 92 522-528.

Chen AM, Perrin MH, Digruccio MR, Vaughan JM, Brar BK, Arias CM, Lewis KA, Rivier JE, Sawchenko PE \& Vale WW 2005 A soluble mouse brain splice variant of type 2 alpha corticotropin-releasing factor (CRF) receptor binds ligands and modulates their activity. PNAS 102 2620-2625. 
Chrousos GP 1995 The hypothalamic-pituitary-adrenal axis and immune-mediated inflammation. New England Journal of Medicine 332 1351-1362.

Coste SC, Heldwein KA, Stevens SL, Tobar-Dupres E \& Stenzel-Poore M 2001 IL-1 alpha and TNF alpha down-regulate CRH receptor-2 mRNA expression in the mouse heart. Endocrinology 142 3537-3545.

Craig R, Larkin A, Mingo AM, Thuerauf DJ, Andrews C, McDonough PM \& Glembotski CC 2000 p38 MAPK and NF-kappa B collaborate to induce interleukin- 6 gene expression and release, evidence for a cytoprotective autocrine signaling pathway in a cardiac myocyte model system. Journal of Biological Chemistry 275 23814-23824.

Davis ME, Pemberton CJ, Yandle TG, Fisher SF, Lainchbury JG, Frampton CM, Rademaker MT \& Richards AM 2007 Urocortin 2 infusion in healthy humans: hemodynamic, neurohormonal, and renal responses. Journal of the American College of Cardiology 49 461-471.

Deliargyris EN, Raymond RJ, Theoharides TC, Boucher WS, Tate DA \& Dehmer GJ 2000 Sites of interleukin-6 release in patients with acute coronary syndromes and in patients with congestive heart failure. American Journal of Cardiology 86 913-918.

Fisman EZ, Benderly M, Esper RJ, Behar S, Boyko V, Adler Y, Tanne D, Matas Z \& Tenenbaum A 2006 Interleukin-6 and the risk of future cardiovascular events in patients with angina pectoris and/or healed myocardial infarction. American Journal of Cardiology 98 14-18.

Grammatopoulos DK, Randeva HS, Levine MA, Katsanou ES \& Hillhouse EW 2000 Urocortin, but not corticotropin-releasing hormone (CRH), activates the mitogen-activated protein kinase signal transduction pathway in human pregnant myometrium: an effect mediated via R1alpha and R2beta CRH receptor subtypes and stimulation of Gq-proteins. Molecular Endocrinology 14 2076-2091.

Grigoriadis DE \& De Souza EB 1988 The brain corticotropin-releasing factor (CRF) receptor is of lower apparent molecular weight than the CRF receptor in anterior pituitary, evidence from chemical cross-linking studies. Journal of Biological Chemistry 263 10927-10931.

Heldwein KA, Redick DL, Rittenberg MB, Claycomb WC \& Stenzel-Poore MP 1996 Corticotropin-releasing hormone receptor expression and functional coupling in neonatal cardiac myocytes and AT-1 cells. Endocrinology 137 3631-3639.

Huang M, Pang X, Karalis K \& Theoharides TC 2003 Stress-induced interleukin-6 release in mice is mast cell-dependent and more pronounced in apolipoprotein E knockout mice. Cardiovascular Research 59 241-249.

Huber SA, Sakkinen P, Conze D, Hardin N \& Tracy R 1999 Interleukin6 exacerbates early atherosclerosis in mice. Arteriosclerosis and Thrombosis 19 2364-2367.

Ikeda K, Tojo K, Tokudome G, Ohta M, Sugimoto K, Tamura T, Tajima N, Mochizuki S, Kawakami M \& Hosoya T 2003 Cardiac expression of urocortin (Ucn) in diseased heart; preliminary results on possible involvement of Ucn in pathophysiology of cardiac diseases. Molecular and Cellular Biochemistry 252 25-32.

Ikeda K, Tojo K, Otsubo C, Udagawa T, Hosoya T, Tajima N, Nakao K \& Kawamura M 2005 Effects of urocortin II on neonatal rat cardiac myocytes and non-myocytes. Peptides 26 2473-2481.

Jiang W, Babyak M, Krantz DS, Waugh RA, Coleman E, Hanson MM, Frid DJ, McNulty S, Morris JJ, O'Connor CM et al. 1996 Mental stress-induced myocardial ischemia and cardiac events. JAMA $\mathbf{2 7 5}$ $1651-1656$.

Kageyama K, Hanada K, Nigawara T, Furukawa K, Terui K, Ogura E, Motomura S \& Suda T 2007 Inhibitory effects of glucocorticoids on urocortin-mediated increases in interleukin-6 gene expression in rat aortic smooth muscle cells. Peptides 28 1059-1067.

Karalis K, Louis JM, Bae D, Hilderbrand H \& Majzoub JA 1997 CRH and the immune system. Journal of Neuroimmunology 72 131-136.

Kempuraj D, Papadopoulou NG, Lytinas M, Huang M, KandereGrzybowska K, Madhappan B, Boucher W, Christodoulou S, Athanassiou A \& Theoharides TC 2004 Corticotropin-releasing hormone and its structurally related urocortin are synthesized and secreted by human mast cells. Endocrinology $14543-48$.
Kimura Y, Takahashi K, Totsune K, Muramatsu Y, Kaneko C, Darnel AD, Suzuki T, Ebina M, Nukiwa T \& Sasano H 2002 Expression of urocortin and corticotropin-releasing factor receptor subtypes in the human heart. Journal of Clinical Endocrinology and Metabolism 87 340-346.

Knight RA, Chen-Scarabelli C, Yuan Z, McCauley RB, Di RJ, Scarabelli GM, Townsend PA, Latchman D, Saravolatz L, Faggian G et al. 2008 Cardiac release of urocortin precedes the occurrence of irreversible myocardial damage in the rat heart exposed to ischemia/reperfusion injury. FEBS Letter $\mathbf{5 8 2}$ 984-990.

Kohno M, Kawahito Y, Tsubouchi Y, Hashiramoto A, Yamada R, Inoue KI, Kusaka Y, Kubo T, Elenkov IJ, Chrousos GP et al. 2001 Urocortin expression in synovium of patients with rheumatoid arthritis and osteoarthritis: relation to inflammatory activity. Journal of Clinical Endocrinology and Metabolism 86 4344-4352.

Kokkotou E, Torres D, Moss AC, O'Brien M, Grigoriadis DE, Karalis K \& Pothoulakis C 2006 Corticotropin-releasing hormone receptor 2-deficient mice have reduced intestinal inflammatory responses. Journal of Immunology 177 3355-3361.

Kounis NG, Hahalis G \& Theoharides TC 2007 Coronary stents, hypersensitivity reactions and the Kounis syndrome. Journal of Invasive Cardiology 20 314-323.

Krantz DS, Sheps DS, Carney RM \& Natelson BH 2000 Effects of mental stress in patients with coronary artery disease: evidence and clinical implications. Journal of the American Medical Association 283 1800-1802.

Latchman DS 2003 Urocortin protects against ischemic injury via a MAPK-dependent pathway. Trends in Cardiovascular Medicine 11169.

Li RCX, Ping P, Zhang J, Wead WB, Cao X, Gao J, Zheng Y, Huang S, Han J \& Bolli R 2001 PKCe modulates NF-kB and AP-1 via mitogen-activated protein kinases in adult rabbit cardiomyocytes. American Journal of Physiology. Heart and Circulatory Physiology 279 $1679-1689$.

Luc G, Bard JM, Juhan-Vague I, Ferrieres J, Evans A, Amouyel P, Arveiler D, Fruchart JC \& Ducimetiere P 2003 C-reactive protein, interleukin-6, and fibrinogen as predictors of coronary heart disease: the PRIME Study. Arteriosclerosis, Thrombosis and Vascular Biology 23 1255-1261.

Mackay KB, Stiefel TH, Ling N \& Foster AC 2003 Effects of a selective agonist and antagonist of CRF2 receptors on cardiovascular function in the rat. European Journal of Pharmacology 469 111-115.

Miyao Y, Yasue H, Ogawa H, Misumi I, Masuda T, Sakamoto T \& Morita E 1993 Elevated plasma interleukin-6 levels in patients with acute myocardial infarction. American Heart Journal 1261304.

Nishikimi T, Miyata A, Horio T, Yoshihara F, Nagaya N, Takishita S, Yutani C, Matsuo H, Matsuoka H \& Kangawa K 2000 Urocortin, a member of the corticotropin-releasing factor family, in normal and diseased heart. American Journal of Physiology. Heart and Circulatory Physiology 279 H3031-H3039.

Nukina H, Sudo N, Aiba Y, Oyama N, Koga Y \& Kubo C 2001 Restraint stress elevates the plasma interleukin-6 levels in germ-free mice. Journal of Neuroimmunology 115 46-52.

Okosi A, Brar BK, Chan M, D'Souza L, Smith E, Stephanou A, Latchman DS, Chowdrey HS \& Knight RA 1998 Expression and protective effects of urocortin in cardiac myocytes. Neuropeptides 32 167-171.

Packard RR \& Libby P 2008 Inflammation in atherosclerosis: from vascular biology to biomarker discovery and risk prediction. Clinical Chemistry 54 24-38.

Pisarchik A \& Slominski A 2004 Molecular and functional characterization of novel CRFR1 isoforms from the skin. European Journal of Biochemistry 271 2821-2830.

Pournajafi NH, Tanaka Y, Dorobantu M \& Hashimoto K 2003 Modulation of corticotropin-releasing hormone receptor type 2 mRNA expression by CRH deficiency or stress in the mouse heart. Regulatory Peptides 115 131-138. 
Purcell NH, Tang G, Yu C, Mercurio F, DiDonato JA \& Lin A 2001 Activation of NF-kappa B is required for hypertrophic growth of primary rat neonatal ventricular cardiomyocytes. PNAS 986668 6673.

Sano M, Fukuda K, Kodama H, Pan J, Saito M, Matsuzaki J, Takahashi T, Makino S, Kato T \& Ogawa S 2000 Interleukin-6 family of cytokines mediate angiotensin II-induced cardiac hypertrophy in rodent cardiomyocytes. Journal of Biological Chemistry $\mathbf{2 7 5}$ 29717-29723.

Schulman D, Latchman DS \& Yellon DM 2003 Urocortin protects the heart from reperfusion injury via upregulation of p42/p44 MAPK signaling pathway. American Journal of Physiology. Heart and Circulatory Physiology $283 \mathrm{H} 1481-\mathrm{H} 1488$.

Shi M, Yan X, Ryan DH \& Harris RB 2000 Identification of urocortin mRNA antisense transcripts in rat tissue. Brain Research Bulletin $\mathbf{5 3}$ 317-324.

Theoharides TC \& Cochrane DE 2004 Critical role of mast cells in inflammatory diseases and the effect of acute stress. Journal of Neuroimmunology 146 1-12.

Theoharides TC, Donelan JM, Papadopoulou N, Cao J, Kempuraj D \& Conti P 2004 Mast cells as targets of corticotropin-releasing factor and related peptides. Trends in Pharmacological Sciences $\mathbf{2 5}$ 563-568.

Townsend PA, Davidson SM, Clarke SJ, Khaliulin I, Carroll CJ, Scarabelli TM, Knight RA, Stephanou A, Latchman DS \& Halestrap AP 2007 Urocortin prevents mitochondrial permeability transition in response to reperfusion injury indirectly by reducing oxidative stress. American Journal of Physiology. Heart and Circulatory Physiology 293 928-938.

Tsatsanis C, Androulidaki A, Dermitzaki E, Gravanis A \& Margioris AN 2007 Corticotropin releasing factor receptor 1 (CRF1) and CRF2 agonists exert an anti-inflammatory effect during the early phase of inflammation suppressing LPS-induced TNF-alpha release from macrophages via induction of COX-2 and PGE2. Journal of Cell Physiology 210 774-783.

Waser B, Rehmann R, Rivier J, Vale W \& Reubi JC 2006 CRF receptors in the rodent and human cardiovascular systems: species differences. Peptides 27 3029-3038.

Woodcock EA 2004 Ucn-II and Ucn-III are cardioprotective against ischemia reperfusion injury: an essential endogenous cardioprotective role for CRFR2 in the murine heart. Endocrinology 145 21-23.

Wu Y, Zhou H, Xu Y \& Li S 2006 Enhanced expression of urocortin in lung tissues of rats with allergic asthma. Biochemical and Biophysisical Research Communications 341 532-540.

Yamauchi-Takihara K, Ihara Y, Ogata A, Yoshizaki K, Azuma J \& Kishimoto T 1995 Hypoxic stress induces cardiac myocyte-derived interleukin-6. Circulation 91 1520-1524.

Received in final form 18 January 2009

Accepted 11 February 2009

Made available online as an Accepted Preprint 11 February 2009 